\title{
Core Capability and Competitive Strategy for Construction Firms in China at the International Market
}

\author{
Shi-Gang YAN \\ China Foreign Affairs University \\ Beijing, P.R. China \\ E-mail: yanshigang@cfau.edu.cn
}

\begin{abstract}
Chinese construction firms (CCFs) played an important role at the international market. As an important participant at the international construction market, Chinese construction firms are confronted with the tasks of keeping themselves competitive. The paper analyzed the current situation of CCFs at the international construction Market. To help construction firms maintain and improve their competitiveness, this research builds a conceptual model to investigate the relationship between core capability and competitive strategy within Chinese construction firms.
\end{abstract}

Keywords- construction firms, China, core capability, competitive strategy

\section{INTRODUCTION}

With the rapid development of the Chinese construction industry, increasing support from the government, and China's internationalization, Chinese construction firms (CCFs) have been given great opportunities in venturing abroad and acquiring wide-ranging experience, enhancing their knowledge and skills. Some CCFs have made significant achievements in the global construction market. The number of CCFs that have emerged in the Engineering News Record (ENR) Top 250 International Contractors list has increased from a mere 4 in 1992 to 65 in 2015.

The rapid emergence of CCFs in international markets has generated much interest in their competitors around the globe as well as in researchers (Cheah et al., 2007; Chen \&Orr, 2014; Co, 2014). Although CCFs have had great achievements in recent years, their international market share is still relatively small compared to the more established contractors from advanced industrialized countries (AICs). International competitiveness must be improved significantly if they want to make a bigger foray into international markets. However, based on extensive literature review, it was found that there are few empirical studies on how to improve CCFs' international performance, especially from the corporate perspectives. The purpose of this study is to understand the determinants of CCFs. Drawing on the resource-based view and industry organization approach, the study focuses on investigating the core capability and competitive strategy in affecting CCFs' international performance.

\section{THE DEVELOPMENT OF CCFS AT THE INTERNATIONAL CONSTRUCTION MARKET}

\section{A. Current Situation Of International Construction Market}

Engineering News Records (ENR) defined the international construction market as the specified volume open to foreign construction firms in the international market. The International construction 2020 report forecasted that construction in emerging markets would double in size over the next decade, growing by an estimated $110 \%$ to become a market worth $\$ 7$ trillion, representing a massive $17.2 \%$ of international GDP in 2020 (Parsa et al., 2015).

The increasing international construction market could be supported by the ENR's annual statistics, which has shown that Top 250 International contractors have increased their revenue in the international markets over the last decade (ENR, 2016). In comparing the top 250 international contractors over the past decade, the revenue generated by these firms has increased from US $\$ 224.4$ billion in 2006 to US\$544.0 billion in 2015(ENR, 2016); therefore it can be stated that large international contractors are finding an abundance of work in the international market.

\section{B. The Market Share of CCFs at The International \\ Construction Market}

In 2015, the gross contracting revenue of the 65 Chinese contractors reached US\$ 93.7 billion and accounted for $19.3 \%$ of the top 250 contractor's revenue (ENR, 2016). The Africa market contributed to US\$ 35.4 billion and accounted for $54.9 \%$ of their international revenues for the top 65 Chinese contractors. The revenue for Top 65 Chinese contractors at Asia reached US\$30.2 billion, accounting for $25.0 \%$ of their international revenues. The revenue for Top 65 Chinese contractors at Middle East and Latin America reached US\$ 13.1 billion and US\$ 7.5 billion respectively, accounting for $17.2 \%$ and $13.7 \%$ of their international revenues.

Chinese contractors' share of the international market is still smaller in comparison with their competitors. The international revenue generated by the top 52 European construction firms accounted for $43.6 \%$ of all total 
international revenue received in 2015. The main markets of operation for European contractors can be observed as the United States, Europe and Latin America. In comparison, the top 65 Chinese contractors achieved $19.3 \%$ of total international revenue. This comparison indicates that Chinese contractors should enhance their international competitiveness to achieve wider markets, when compared to their Western counterparts.

\section{Types of Works Undertaken by CCFs}

The types of international construction projects undertaken by CCFs can be categorized as follows: general building, transportation, power, petrochemical, manufacturing, sewage treatment, water supply, telecommunication projects, etc. (Zhao and Shen, 2008).

In 2015, the top three types of works involving CCFs are general building, transportation and petrochemical projects. There is a trend from 2011 to 2015 towards more diversification in CCFs' construction business. General building works remain the biggest share. More projects involving high technology and financial requirements have been undertaken, including large industrial manufacturing, power, water supply and telecommunication works.

\section{A THEORETICAL MODEL TO ANALYZE COMPETITIVE ADVANTAGE OF CCFS}

The concept of competitive advantage has received much academic attention and has become well established in the literature (Barney, 1991; Teece et al., 1997). Regardless of which theoretical perspective is represented, there is a general agreement that the purpose of strategic competitive activity in the firm is to achieve a sustainable competitive advantage, and thereby enhance a business' performance (Porter, 1985; Carpano et al., 1994).

\section{A. Core Capability and Competitive Advantage of CCFs}

The resource-based view focuses on the firm's resources and capabilities to understand business strategy and to provide direction to strategy formulation. Resources include financial resources, tangible resources (such as plant, equipment, buildings), and intangible resources (such as patent, know-how, brand) (Barney, 1991). According to Teece et al. (1997), resources are firm specific assets that are difficult to imitate because of transaction costs and tacit knowledge. These resources are the basis of the company's superior economic performance, and constitute organizational routines or core competence (Prahalad \& Hamel, 1990). Through the internationalization process, firms gradually expand their business activities beyond their national authority and launch operations in other countries (Ahmad \& Kitchen, 2008). Resources and core capabilities are important for the internationalization of any firm. The presence of resources and capabilities could provide a firm the discretion or motivation (strategic choices) to pursue a strategy of internationalization thereby increasing its size and profitability (Knight\& Kim, 2009). Moreover, a firm can develop new capabilities as they expand internationally. These new capabilities, along with their existing resources, help the firm compete in the international market.
With the globalization of the world economy, construction markets in most countries are gradually opening to foreign contractors. International contractors from different countries tend to adopt different strategies to compete internationally. To achieve success in the international construction market, CCFs need to upgrade their organizational capabilities through operations in new countries and markets. Cheah et al. (2007) identified seven strategic fields and two internal mechanisms of organization for large global engineering and construction firms. These issues exist at the corporate level and are embedded in the very lifeblood of the organization, and hence reflect the corresponding firm-specific resources and capabilities. Chen \& Orr (2014) analyzed the mechanisms of Chinese contractors' entry into Africa and stated Chinese contractors' performance in Africa in terms of business revenue actually hinges upon availability of financing sources and availability of natural resources. Gaur et al. (2014) identified three critical resource/capability variables, namely international experience, marketing and technological capabilities to study the competitive advantage of Chinese firms in the international market.

Thus, it expects CCFs with a wide variety of capabilities, including marketing capability, financial capability, project management capability, innovation capability, HR management capability, reputation/brand and organizational culture, to have a broader range of possible actions and to be able to exploit numerous resources, thus enhancing CCFs' international performance.

\section{B. Competitive Strategy and Competitive Advantage of CCFs}

The business environment within international construction market is very volatile. Competition from new entrants, social reforms, technological advancement and globalization pose major challenges of growth of this industry. Carpano et al. (1994) studied generic competitive strategies in the international context from two major dimensions: segment differentiation and geographical scope. They also highlighted the importance of cost leadership and differentiation strategies. Pheng et al. (2004) suggested that the relatively low cost of construction machinery, material and equipment from China facilitates the reduction of the bidding price for CCFs. Kaila (2012) focused on the competitive strategies adopted by Chinese contractors in Kenya and stated that the most practiced competitive strategies by Chinese adopted were cost leadership and differentiation strategy. Prasa et al. (2015) found that the international competitiveness of CCFs continued to improve due to relatively low costs and resulting competitive bidding prices. Thus, it expects CCFs to have a broader range of possible actions and rely heavily on developing competitive strategy in order to be sustainable in the international construction market.

The business environment within international construction market is very volatile. Competition from new entrants, social reforms, technological advancement and globalization pose major challenges of growth of this industry. Carpano et al. (1994) studied generic competitive 
strategies in the international context from two major dimensions: segment differentiation and geographical scope. They also highlighted the importance of cost leadership and differentiation strategies. Pheng et al. (2004) suggested that the relatively low cost of construction machinery, material and equipment from China facilitates the reduction of the bidding price for CCFs. Kaila (2012) focused on the competitive strategies adopted by Chinese contractors in Kenya and stated that the most practiced competitive strategies by Chinese adopted were cost leadership and differentiation strategy. Prasa et al. (2015) found that the international competitiveness of CCFs continued to improve due to relatively low costs and resulting competitive bidding prices. Thus, it expects CCFs to have a broader range of possible actions and rely heavily on developing competitive strategy in order to be sustainable in the international construction market.

\section{CONCLUSIONS}

The conceptual model presented herein was a generic framework that allowed industry practitioners and academic researchers to understand, sustain and extend the competitive advantage of Chinese CCFs. The conceptual model implied that Chinese CCFs' competitive advantage depends upon the identification of appropriate strategy and industry structure as well as developing and creating core capability in order to exploit opportunities and neutralize the threats presented by competition. Based on the conceptual model, future research will put forward hypotheses which are built up to test patterns of core capability, competitive strategy on international performance of Chinese CCFs.

\section{ACKNOWLEDGMENT}

The research is supported by Beijing Philosophy and Social Science Fund (No. 16ZGB008).

\section{REFERENCES}

[1] S.Z. Ahmad, and P.J. Kitchen, "International expansion strategies of Malaysian construction firms: Entry mode choice and motives for investment", Problems and Perspectives in Management, Vol.6, No.3, pp.15-23, 2008.

[2] J.B. Barney, "Firm resources and sustained competitive advantage. Journal of Management", No.17, pp.99-120, 1991.
[3] C. Carpano , J.J. Chrisman, and K. Roth, "International strategy and environment: An assessment of the performance relationship", Journal of International Business Studies, Vol.25,No.3, pp.639-656, 1994.

[4] C. Chen, and R.J. Orr, "Chinese contractors in Africa: home government support, coordination mechanisms and market entry strategies," Journal of Construction Engineering and Management, Vol.135, No.11, pp. 1201-1210, 2014.

[5] C.Y. Co, "Chinese contractors in developing countries," Review of

[6] World Economics, Vol.150, No.1, pp.149-171, 2014.

[7] C.Y.J Cheah,., Kang, J., and D.A.S. Chew, "Strategic analysis

[8] of large local construction companies in China," Construction

[9] Management and Economics, Vol.25, No.1, pp.25-38, 2007.

[10] Engineering News Record (ENR) (2016). The top 225 international contractors. [Online] Available: http://www.enr.com/toplists

[11] /2015_Top_250_International_Contractors (July 10, 2016).

[12] G. Knight and D. Kim, "International business competence and the contemporary firm", Journal of International Business Studies, Vol.40 No.2, pp.255-273, 2009.

[13] S.P. Low, and H.B. Jiang, "Internationalization of Chinese Construction Enterprises", Journal of Construction Engineering and Management, American Society of Civil Engineers, Vol. 129, No. 6, pp. 589-598, 2003.

[14] Parsa, S.Huston, A.Kashyap, and P. Li, "The international competitiveness of Chinese construction firms", European Real Estate Society (ERES) Conference, 24-27th June, 2015, Istanbul, Turkey.

[15] L. S. Pheng, H. B.Jiang and H. Y. L. Christopher, "A comparative study of top British and Chinese international contractors in the global market," Construction Managment and Economics, No...22, pp.717731, 2004.

[16] M.E. Porter, The Competitive Advantage .New York NY:Free Press, 1985.

[17] D.J. Teece, G. Pisano and A. Shuen, "Dynamic capabilities and strategic management," Strategic Management Journal, Vol.18, No.7, pp.509-533, 1997.

[18] R. T. Wilson, and D. W. Baack, "Attracting foreign direct investment: Applying Dunning's location advantages framework to FDI advertising," Journal of International Marketing, Vol.20, No. 2, pp.96115,2012

[19] S.G. Yan and G.Z. Liu, "Competitive strategy, market entry mode and international performance: Business and Management Studies, vol. 3 , No.1, pp. 1-9, 2017.

[20] Z. Y. Zhao, and L. Y. Shen, "Are Chinese contractors competitive in international market?" Construction Management and Economics, Vol.26, No.26,pp.225-236, 2008 